\title{
Estudo da cerâmica do sítio arqueológico Alvorada, da região do Rio Aguapeí, estado de São Paulo
}

\author{
Neide Barrocá Faccio* \\ Hiuri Marcel Di Baco** \\ Juliana Aparecida Rocha Luz*** \\ André Felipe Alves****
}

FACCIO, N.B.; BACO, H.M.D; LUZ, J.A.R.; ALVES, A.F. Estudo da cerâmica do sítio arqueológico Alvorada, da região do Rio Aguapé́, estado de São Paulo. R. Museu Arq. Etn., São Paulo, n. 21, p. 275-292, 2011.

Resumo: $\mathrm{O}$ estudo da cerâmica do Sítio Arqueológico Alvorada, localizado no Município de Junqueirópolis, SP, teve por objetivo a obtenção de informações sobre a população indígena que ocupou a área. A incorporação dessas informações à memória regional e nacional é extremamente valiosa, dadas as características do sítio e as lacunas existentes na memória histórica regional. A cerâmica encontrada no Sítio Arqueológico Alvorada tem características da cerâmica Tupiguarani; verificamos, contudo, a presença de traços de outra tradição arqueológica, o que sugere alguma forma de contato entre os grupos dos troncos linguísticos tupi-guarani e Jê.

Palavras-Chave: Cerâmica - Tradição Tupiguarani - Sítio arqueológico Alvorada - Memória Nacional.

\section{Introdução}

O Sítio Arqueológico Alvorada foi evidenciado no Município de Junqueirópolis, SP, no interior paulista. Numa avaliação

(*) Faculdade de Ciências e Tecnologia, Universidade Estadual Paulista-FATEC/UNESP, Presidente Prudente, SP. <nfaccio@terra.com.br>

${ }^{(* *)}$ Mestrando em Arqueologia pelo Museu de Arqueologia e Etnologia, Universidade de São Paulo. 〈hiuridibaco@gmail.com> $\left.{ }^{(* *}\right)$ Mestre em Arqueologia pelo Museu de Arqueologia e Etnologia, Universidade de São Paulo.<juliluzz@yahoo.com.br> $\left({ }^{* * * *}\right)$ Graduando em Geografia da Faculdade de Ciências e Tecnologia, Universidade Estadual Paulista-FATEC/UNESP, Presidente Prudente, SP. <alves_andre_felipe@hotmail.com> preliminar, esse sítio encontrava-se em situação de alto risco e em avançado estado de degradação, pelo uso do arado e do subsolador. A abertura de buracos profundos para a construção de curvas de nível retirou o material arqueológico de seu contexto original e colaborou para que os fragmentos cerâmicos se partissem em pedaços ainda menores. O Sítio Arqueológico Alvorada foi datado de $530 \pm 70 \mathrm{AP}$.

No entorno da área desse sítio, foram encontrados mais três outros sítios arqueológicos: Alvorada II, Alvorada III e Alvorada IV. (Fig. 1).

No entanto, neste texto, nosso objetivo é apresentar, detalhadamente, os resultados dos estudos para a área do Sítio Alvorada. Os Sítios Alvorada e Alvorada IV apresentaram 
um maior número de registros arqueológicos, o que aumentou as possibilidades de análise. Os Sítios Alvorada II e III continham apenas uma fração do montante encontrado nos outros dois sítios, além do fato de que o tamanho e o estado de conservação dos seus fragmentos dificultaram uma análise mais pormenorizada deles.

O estudo do material resgatado na área do Sítio Alvorada permitiu constatar que a cerâmica apresenta características singulares. Isto porque, embora classificada na Tradição Tupiguarani (grupo linguístico tupi-guarani), alguns fragmentos apresentaram brunidura, ainda que em pequena quantidade, relacionada ao grupo linguístico Jê, ou à Tradição Itararé. Ainda, um fragmento de borda depois de ter seu contorno reconstituído graficamente, apresentou forma dupla, forma essa que é comum na Tradição Aratu, também associada ao grupo linguístico Jê, no norte do Estado de São Paulo.

Diante da presença desses poucos elementos (forma da vasilha e brunidura) identificados na nossa análise e classificados pela literatura arqueológica brasileira como característicos do grupo linguístico Jê, em um sítio tupi-guarani, levantamos algumas questões.

Seria possível aventar a hipótese de que o grupo indigena que, no passado, habitou os sítios em estudo (índios do tronco linguístico tupi-guarani), manteve contato com grupo indigena de outra etnia, especificamente do tronco linguístico Jê? De qualquer forma, acreditamos que a região em estudo, Bacia do Rio Aguapeí, foi uma área de intensa interação cultural.

Os dados arqueológicos e etno-históricos apontam para uma possível interação entre grupos Guarani e Kaingang na região do Rio Aguapeí, devendo lembrar, porém, que os kayapó estavam no entorno dessa região. De acordo com o Mapa Etno-Histórico de Nimuendajú (1944) esses grupos habitavam territórios vizinhos, no final do século XIX e começo do século XX. Se esse cenário geográfico se manteve também em períodos pré-coloniais, é provável ter existido, mesmo, algum tipo de interação entre esses grupos (Fig. 2).
Sendo assim, os procedimentos adotados durante a realização da pesquisa tiveram por objetivo evitar a perda das informações evidenciadas na cultura material contida nos registros arqueológicos e contribuir para o entendimento dos processos culturais abrangendo as populações indígenas pretéritas, a fim de incorporá-las à história regional e nacional.

\section{Contextualização geral da pesquisa na área do Sítio Alvorada}

Cada grupo indígena desenvolveu uma cultura, no âmbito material e imaterial, adaptada aos seus costumes, crenças, necessidades de sobrevivência, entre outras. As populações indígenas valiam-se do conhecimento das técnicas de fazer utensílios para transmitir informações às gerações seguintes, por meio da interação entre os indivíduos. Nessa interação, transmitiam-se consciente ou inconscientemente diferentes ideias, que poderiam ser funcionais, sociais, comportamentais, ou seja, diversos fatores que, juntos, compunham a cultura desses povos.

A forma específica de apropriação da natureza varia, o que pode ser percebido e estudado por meio dos objetos técnicos (artefatos) que o homem criou para realizar tal objetivo, inerente à sua cultura. Nesse processo de interação do homem com o seu meio natural, a tecnologia atua como um mecanismo de intermediação, a partir do qual é definido o modo como os homens irão organizar os meios materiais e os conhecimentos para explorar os recursos naturais e transformá-los em produtos culturais (Silva 2000: 225).

A cerâmica e a pedra trabalhada (por lascamento ou polimento) são, por excelência, objetos ligados às atividades de subsistência de grupos pré-coloniais. E, nesse sentido, esses vestígios culturais, por si sós, apresentam uma gama variada de tipos e funcionalidades, mesmo quando analisados dentro de uma mesma tradição cultural. As formas líticas e cerâmicas, bem como a forma e o tamanho dos sítios, a localização, entre outros dados, fornecem in- 

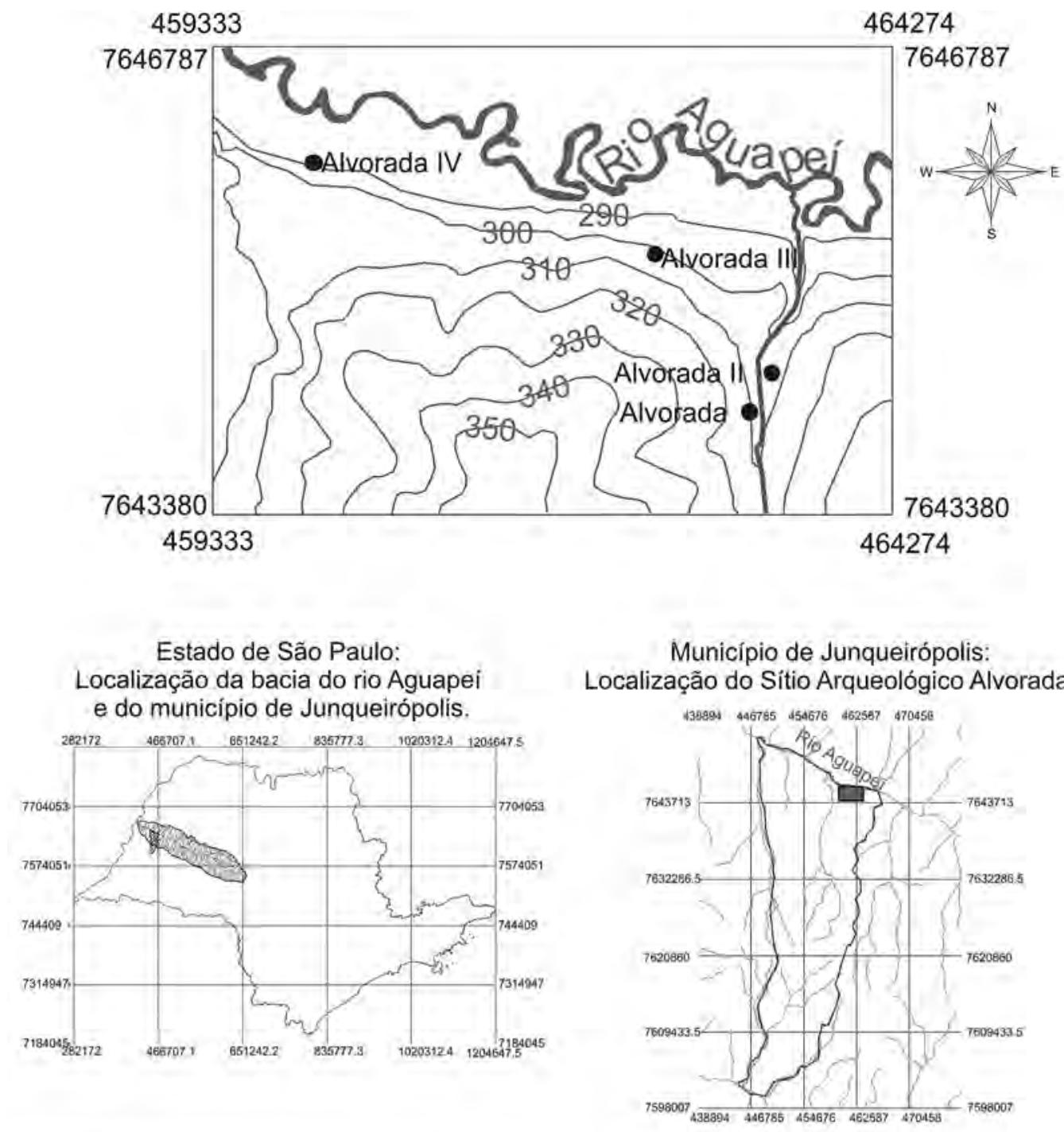

\section{Orientação: \\ Neide Barrocá Faccio \\ Organização: \\ Felipe Augusto Scudeller Zanatta \\ Fonte de dados: \\ IBGE \\ Softwares utilizados: \\ SPRING/ SCARTA (INPE, 2010)}
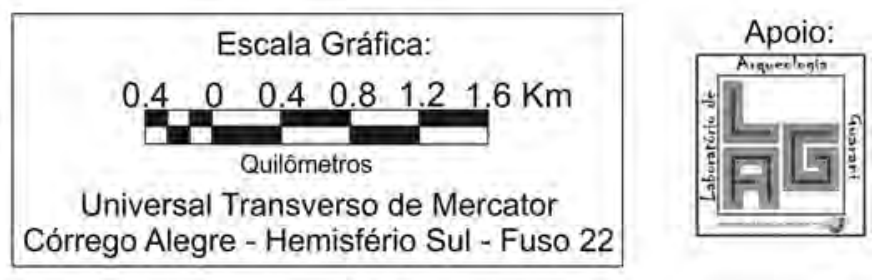

Fig. 1. Localização do Sítio Arqueológico Alvorada. Junqueirópolis, SP.

formações sobre aspectos da cultura, inerentes a cada tipo de produção.

Pesquisas arqueológicas de caráter sistemático não foram desenvolvidas nessa região; contudo, da Bacia do Rio Paraná, onde se insere o Rio Aguapeí, podemos contar com algum conhecimento sobre a Arqueologia Regional. 


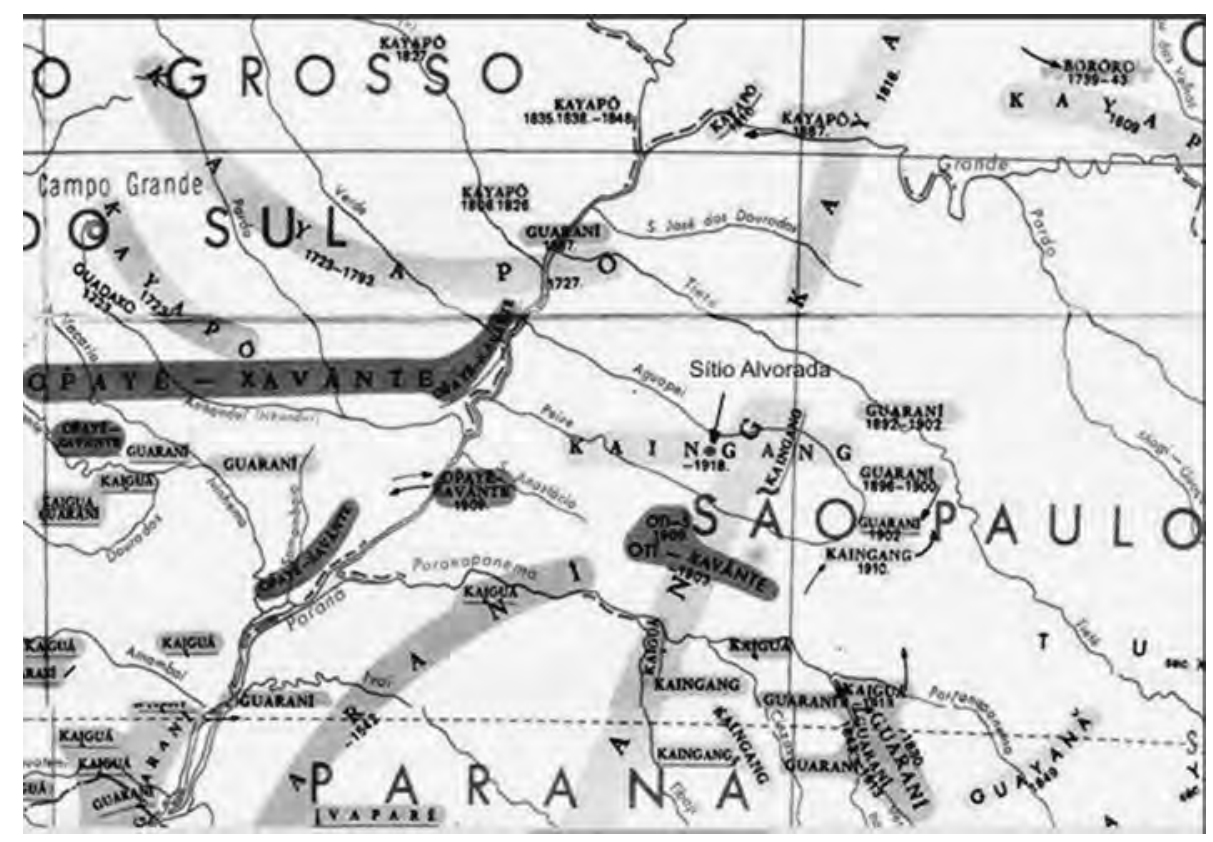

Fig. 2. Mapa Etno-Histórico do Brasil e Regiões Adjacentes, IBGE (1980). Adaptado do Mapa de Curt Nimuendajú (1944). Nesta figura verificamos a localização do Sítio Alvorada na região do Rio Aguapeí.

Em decorrência dessas pesquisas, é possivel conhecer, ainda que em parte, o "Sistema Regional de Ocupação"1 da área.

Pressupostos teóricos utilizados para a análise dos materiais arqueológicos

A área do Sítio Alvorada apresentou-se bastante perturbada pela ação antrópica. Mesmo assim, as análises realizadas para o material cerâmico contemplaram as discussões tecnológicas, análises de cadeia operatória (ou seja, de produção/distribuição/uso/reciclagem/descarte de artefatos) e estilísticas.

Nesse sentido, o pressuposto básico foi tomar os fragmentos cerâmicos, enquanto

(1) Morais (1999: 8) define um Sistema Regional de Povoamento ou de Ocupação como uma coordenação entre sítios ou conjuntos de sítios, pautada por relações sociais, econômicas e culturais (considerando sua contemporaneidade, similaridade ou complementaridade). "Refere-se à dispersão das populações pelo ecúmeno terrestre e à consequente produção de paisagens, com cenários que se sucedem” (Morais 2006: 207). unidade de estudo. Considerando o objetivo maior da própria Arqueologia o estudo de sociedades humanas, torna-se necessário, na análise de coleções arqueológicas, lidar com unidades culturais de comportamento, de forma a poder relacioná-las com outros aspectos da cultura, dentro de uma perspectiva sistêmica de estudo (Faccio 1998). Trata-se de tomar o artefato como objeto de análise, uma vez que a produção cerâmica é estruturada em padrões e sequências, que não podem ser obtidos por dados isolados (sejam os fragmentos cerâmicos, sejam os atributos classificatórios), mas sim pela maneira como as informações se estruturam entre si, ou se padronizam numa forma de artefato (maiores detalhes desta discussão podem ser encontrados em Arnold (1984), Kingery (1984), Rice (1984), Steponaitis (1983), Schortman (1989) e Hodder (1978).

É certo que, na Arqueologia Brasileira, a grande maioria dos artefatos cerâmicos foi coletada na forma de fragmentos, sendo raras as vasilhas encontradas inteiras. Assim, o encaminhamento proposto foi agrupar os fragmentos provenientes de uma mesma vasilha por meio 
de análises de sua distribuição na área do sítio, dos planos de fratura e dos diferentes atributos tecnológicos e estilísticos (características da pasta, decoração, forma e dimensões). Obtêm-se, com isso, diferentes conjuntos de fragmentos da mesma vasilha, que passam a constituir o objeto inicial de análise.

A adequação dessa perspectiva aos fragmentos cerâmicos coletados na área do Sítio Alvorada exigiu certos procedimentos especiais. Pelo fato de a cerâmica ter sido evidenciada de forma dispersa e muito fragmentada nas áreas dos quatro sítios, a obtenção de "conjuntos de fragmentos da mesma vasilha” não pôde ser feita a contento.

Dessa forma, foram analisados, de forma sistemática, os fragmentos isolados. As análises recaíram na caracterização das propriedades das vasilhas cerâmicas e na discussão sobre a possível cadeia operatória envolvida na produção desses artefatos. Assim, não são os atributos individuais de análise, como tipo de antiplásticos, espessura das peças, queima e outros detalhes que trarão informação sobre as sequências utilizadas na produção dos artefatos e os possiveis padrões comportamentais, mas sim as relações que apresentam entre si. Tal perspectiva, no entanto, só pode ser aplicada a artefatos (aos "conjuntos de fragmentos" que representam as vasilhas).

No entanto, devido à pequena quantidade dos conjuntos evidenciados, a análise da cerâmica pelos conjuntos ficou prejudicada; isso levou a que o reconhecimento das variações tecnológicas apresentadas nos fragmentos cerâmicos fosse definido a partir das diferentes peças do sítio, e não a partir dos conjuntos de fragmentos de uma mesma vasilha. Tal procedimento, se não é o ideal, foi o que se conseguiu, dado o estado de conservação do sítio em tela.

Dentro desse contexto, procuramos adotar metodologias de análise que permitissem, ao menos, proceder a uma minuciosa caracterização das vasilhas, bem como obter os primeiros elementos para discussões sobre a cadeia operatória envolvida na produção desses artefatos.

A reconstrução dessa suposta cadeia operatória envolvida na confecção do artefato cerâmico é um processo retroativo que utiliza as interpretações de outras ciências como a antropologia, a etno-história e a geografia. O processo deverá abarcar toda a história do artefato cerâmico, desde a aquisição de matéria-prima, até os diferentes estágios de sua produção, seu uso e, finalmente, o seu abandono.

Tal análise permite um estudo mais amplo em relação às investigações tradicionais que levavam em conta apenas a tipologia das peças. "O estudo tecnológico prende-se ao entendimento de como determinada matéria-prima se transformou num utensílio pré-histórico" (Morais 1983: 78).

Conforme tem sido a práxis, "a análise do material cerâmico compreende a verificação de classes de atributos tecnológicos, estilísticos e morfológicos, além das marcas de uso e do estado de conservação" (Faccio 1998: 134).

Segundo Prous (1992), "nas Américas, [...] o forno nunca veio a ser conhecido e a cerâmica era queimada em fogueiras simples, cobrindo-se os potes com lenha" (Prous 1992: 94).

Sobre o processo de queima dos potes, Willey (1987) diz que a queima era feita:

\section{[...] a céu aberto ou em fornos.}

Quando feita em fogueiras produzia vasos sujos de fuligem, marrons, pretos ou castanhos. [...] Em sua maior parte, a queima a céu aberto foi e é característica das terras baixas orientais e do sul da América do Sul. A queima em forno é típica das regiões andinas (Willey 1987: 233).

Para a análise da queima, presente no fragmento cerâmico, optou-se pela queima dominante. As diferenças na cor indicam diferentes condições de duração da queima, ventilação e temperatura. A presença de núcleo com cor variando do laranja ao amarelo indica uma queima boa, com ventilação suficiente para ocasionar a oxidação da argila. A presença de tons que variam do cinza ao preto indica uma queima incompleta, em baixa temperatura e tempo insuficiente para expelir toda a matéria carbonária da argila (Faccio 1998: 135).

Segundo Scatamacchia (1990), "[...] a decoração seria um outro aspecto que poderia 
indicar uma diferença grupal, pois os arranjos que resultaram nos padrões conhecidos foram obtidos através das normas preferenciais de associação" (Scatamacchia 1990: 80).

A decoração, em geral, está subdividida em decoração plástica e pintura. Segundo Prous (1992), a decoração é dita plástica porque modifica o relevo da peça. Já a pintura, utilizando-se de pigmentos minerais e/ou vegetais, não modifica o relevo da vasilha e é, geralmente, efetuada antes da queima, para obter uma maior fixação dos pigmentos na superfície da peça.

Segundo Maranca (1985), existem duas técnicas utilizadas pelas populações pré-históricas na confecção das vasilhas: a da 'modelagem' e, sobretudo, a do 'acordelado'. A vasilha modelada é feita diretamente, a partir do bloco da argila úmida, utilizando-se para isto as mãos. Por sua vez, as vasilhas acordeladas são confeccionadas por meio da sobreposição de cordéis feitos de argila a partir de uma base em forma de espiral.

As cerâmicas na área da Bacia do Rio Paraná, SP, na qual a área do sítio está inserida apresentam os seguintes tipos de bordas: direta inclinada externa; direta inclinada externa (com reforço interno longo); direta inclinada externa (reforçada externa); direta inclinada interna; direta inclinada interna (com suporte para tampa); direta inclinada interna (com ponto angular); direta inclinada interna (com reforço externo longo); direta inclinada interna (reforçada externa); direta vertical; direta inclinada interna (com reforço interno longo); direta vertical reforçada externa; extrovertida inclinada interna; extrovertida inclinada externa; extrovertida inclinada interna reforçada externa; extrovertida inclinada externa reforçada externa; extrovertida inclinada externa (com ponto angular), extrovertida vertical; extrovertida vertical (com ponto angular); extrovertida vertical (reforçada externa); contraída, cambada, infletida e carenada.

Embora a reconstrução gráfica da forma da vasilha seja feita a partir da análise das bordas, essa tarefa é um tanto quanto difícil e polêmica, principalmente, quando se trata de fragmentos de borda de tamanho pequeno, porque, nesse caso, a reconstrução gráfica da forma da vasilha não é totalmente confiável.
Apesar dessa deficiência da reconstrução gráfica das vasilhas, ela foi feita com vistas a levantar hipóteses sobre as formas que tais vasilhas poderiam ter. Sendo assim, reduzimos a reconstrução das amostras, procedendo às projeções, somente quando conseguimos fragmentos de borda que puderam indicar a forma geral da vasilha.

O estudo de técnicas para o restauro de vasilhas indígenas arqueológicas tem contribuído para a divulgação e conscientização no Museu de Arqueologia de Iepê, ${ }^{2}$ SP, a respeito das culturas de grupos indígenas, importantes na formação do povo e da cultura local e do país. Vasilhas fragmentadas, ou em processo de deterioração, antes guardadas nas prateleiras de reservas técnicas de museus, com a remontagem e o restauro podem fazer parte das coleções em exposição e, assim, passam a contribuir mais efetivamente para o conhecimento de uma história pouco conhecida - a do índio brasileiro.

Quanto à metodologia de reconstrução da forma da vasilha cerâmica por modelagem, esta se inicia a partir de um fragmento de borda cujo contorno e diâmetro de circunferência seja de tamanho considerável. É feita, então, a reconstrução gráfica da forma da vasilha, num croqui, em papel manteiga. Esse papel é ideal para projeção do desenho da forma da vasilha, por ser translúcido. Em seguida, utilizando a porcentagem do diâmetro da circunferência da vasilha, (mínimo de 10\%) constrói-se um gabarito, que é uma projeção da vasilha tal como ela seria realmente. Inicia-se o trabalho de reconstrução da vasilha utilizando uma massa composta por argila, cola branca e areia lavada fina. Nessa etapa do trabalho, modela-se a vasilha projetada no croqui.

Em relação à metodologia de remontagem e restauro de vasilhas cerâmicas, inicia-se o trabalho separando os fragmentos em conjuntos de espessura semelhantes. Os fragmentos mais espessos, geralmente, são os da base da vasilha e os mais finos, da sua parede. Deve-se começar a colagem, utilizando uma mistura de argila com

(2) O material do Sítio Arqueológico Alvorada está sob a guarda do Museu de Arqueologia de Iepê (MAI). 
cola branca (Faccio 1991). Primeiro, juntam-se os fragmentos constituintes da base, depois os da parede. Após o processo de colagem, devem-se preencher as fissuras - que vão aparecer, naturalmente, com o decorrer da secagem dos fragmentos colados - com mais mistura de argila e cola branca. Em seguida, com uma flanela umedecida com água, retira-se o excesso de cola, completando o trabalho de colagem. Para o acabamento final, utiliza-se uma mistura de tonalidades de tintas guache, que é solúvel em água, para disfarçar a cor da mistura cola/ argila que ficou entre o contato das superfícies coladas, terminando assim a fase de remontagem e restauro da peça.

$\mathrm{O}$ aspecto principal para a distinção entre as formas baseia-se na relação entre diâmetro da circunferência e altura da vasilha. Com isso, essas variáveis refletem um sentido cultural e são usadas de forma simplificada para facilitar o emprego dos testes estatísticos.

O trabalho etno-histórico produzido pelo padre espanhol Antônio Ruiz de Montoya, a partir da convivência entre índios Guarani na região entre o oeste do Paraná, o noroeste do Rio Grande do Sul e o nordeste da Argentina, na primeira metade do século XVII, traz informações sobre a cerâmica Guarani, fazendo menção a algumas vasilhas produzidas por aqueles povos, com suas características físicas e sociais (funcionalidade). Assim, analisa-se a forma e a funcionalidade da vasilha (seja na forma inteira ou reconstruída graficamente). Para a área do Sítio Alvorada os dados etno-históricos apontam para uma área de ocupação Guarani. No atual estágio das pesquisas, no entanto, não podemos afirmar com segurança se a cerâmica, em estudo, é Guarani ou Tupi, tendo em vista o fato de o Sítio Alvorada estar localizado em uma região do Estado de São Paulo, conhecida como de fronteira entre Guarani e Tupi, estando os Guarani localizados no sul e os Tupi no norte do Estado. Dessa forma, não podemos discernir o que é Tupi do que seja Guarani, tendo em vista as semelhanças que apresentam os materiais dessas duas etnias. Diante do exposto, é nosso objetivo, na continuidade de nossas pesquisas, investigar as semelhanças e as diferenças entre as cerâmicas Tupi e Guarani do Estado de São Paulo.

\section{Os materiais resgatados no contexto do Sítio Alvorada}

No Sítio Alvorada, foi evidenciada uma grande variabilidade de peças cerâmicas. Essa variabilidade é muito comum em sítios arqueológicos da Tradição Tupiguarani. Além do material cerâmico, evidenciou-se um chooper em seixo de silexito.

$\mathrm{O}$ estudo dos vestígios dos sítios arqueológicos em tela permitiu, ao menos em parte, conhecer a história dos índios que os confeccionaram.

\section{A cerâmica do Sítio Alvorada}

A análise quantitativa dos atributos tecno-morfológicos da cerâmica de determinado sítio ᄀé uma das principais fases do estudo, pois possibilita o levantamento de dados a respeito das particularidades tecnológicas desenvolvidas por uma sociedade em determinado tempo e espaço. Neste texto, apresentamos a quantificação e a análise de dados de alguns atributos referentes às peças coligidas na área do Sítio Alvorada.

Na Tabela 1, podemos ver a classe (parte da vasilha) a que pertencem os 685 fragmentos analisados do Sítio Alvorada. Na leitura da Tabela 1 , podemos constatar que a maior parte dos fragmentos (245 peças) é composta por paredes. Nada mais comum, haja vista que a parede, salvo raras exceções, compõe a maior parte da vasilha.

Tabela 1

\begin{tabular}{lrl}
\hline \multicolumn{3}{c}{$\begin{array}{c}\text { Classe dos fragmentos encontrados } \\
\text { Sítio Alvorada, Junqueiropólis, }\end{array}$} \\
\hline \hline \multicolumn{1}{c}{ Classe } & No & $\%$ \\
\hline Parede & 245 & 35,7664 \\
Borda & 176 & 25,6934 \\
Base & 146 & 21,3139 \\
Parede angular & 38 & 5,5474 \\
Parede e base & 4 & 0,5839 \\
Borda com suporte para tampa & 1 & 0,146 \\
Calibrador & 31 & 4,5255 \\
Vasilha conjugada & 2 & 0,292 \\
Fragmentos de bolotas de argila & 19 & 2,7737 \\
Não identificada & 23 & 3,3577 \\
\hline Total & 685 & 100 \\
\hline
\end{tabular}


Do Sítio Alvorada, foram analisadas 176 bordas. Os fragmentos de base corresponderam a 146 peças. As demais classes identificadas foram: as paredes angulares ( 38 peças); os fragmentos de parede e base (quatro peças); as paredes reaproveitadas como "calibradores" 3 (31 peças); borda com suporte para tampa (uma peça) e fragmentos de bolotas de argila (19 peças).

Outros vestígios cerâmicos que geram muita discussão são os fragmentos de bolotas de argila. Uma reavaliação, aliada a novas evidências arqueológicas, nos permite fazer inferências para explicar o significado desses objetos encontrados nos Sítios Tupiguarani. Três desses fragmentos de bolotas possuem marcas de unha.

É provável que os fragmentos de bolota sejam, na verdade, fragmentos de suporte de panela, mas, devido ao pequeno tamanho deles, permitem apenas a hipótese. ${ }^{4}$

Assim, a brunidura encontrada em alguns fragmentos cerâmicos do Sítio Alvorada também merece ser estudada mais detalhadamente. O estudo proposto poderá trazer novas informações sobre essa técnica, pois correlaciona as propriedades da argila e as diferentes manipulações e seleção de temperos e tratamentos de superfície escolhidos por esses antigos ceramistas.

$\mathrm{O}$ antiplástico utilizado de forma predominante foi o caco moído ( 585 peças, ou $85,4015 \%$ do total). Em menor porcentagem está o mineral ( 82 peças, ou $11,9708 \%$ ), que pode ter sido misturado acidentalmente ou intencionalmente à pasta, visando dar- lhe uma maior resistência e plasticidade. Devido ao mau estado de conservação, não nos foi possível identificar o antiplástico de 18 peças $(2,6277 \%$ do total).

A técnica do roletamento ou acordelamento foi identificada nas análises em 525 peças

(3) Acreditamos que esses objetos podem ter sido utilizados para outro fim; faltam, no entanto, mais estudos para estabelecermos correlações que, juntas, possam fornecer os princípios para explicar a sua função. A Arqueologia Experimental pode ser um dos programas de estudo para realizar uma série de experimentos e testes direcionados à exploração desse problema. (4) Nos sítios arqueológicos Guarani do Baixo Paranapanema são comuns os fragmentos de suporte de panela do tipo lisa, ungulada ou escovada.
(76,6423\% do total). A técnica do modelado, diagnosticada em 126 peças $(18,6862 \%$ do total) é usada, geralmente, para vasilhas pouco profundas e pequenas. Não foi possível a identificação do tipo de manufatura em 34 peças $(4,9635 \%)$.

Após a confecção da vasilha, essa era levada para secar, com o objetivo de que toda a água saísse da argila. Em seguida queimava-se a vasilha. Como essa queima era feita em fornos a céu aberto, nos quais não havia controle de temperatura e nem da entrada de oxigênio, a peça geralmente não queimava por igual. Assim, uma mesma peça apresenta vários tipos de queima.

A queima mais presente foi com seção transversal sem presença de núcleo, com cor uniforme variando do cinza escuro ao preto, seguida da queima do tipo 1 , caracterizada como seção transversal sem presença de núcleo com cor uniforme variando do laranja-tijolo ao amarelo. Não foram identificados os tipos de queima presentes em 54 peças (7,8832\% do total). A queima da cerâmica do Sítio Alvorada foi feita sem controle em fogueiras a céu aberto, tendo muitas peças ficado sem completar a queima.

A cerâmica apresentou os tipos liso (367 dos casos) e decorado (318 dos casos). Os tipos cerâmicos foram definimos de acordo com a terminologia proposta por Chmyz (1976). A decoração plástica ocorreu apenas na face externa das vasilhas (Prancha 1).

A decoração pintada (Pranchas 2, 3, 4 e 5) ocorreu tanto na face interna, na externa, como na interna/externa e quase exclusivamente sobre engobo. Uma única peça mostra pintura diretamente sobre a argila.

Foi possível observar que uma mesma vasilha pode apresentar decorações distintas associadas. A análise dos conjuntos de fragmentos mostrou, por exemplo, peças com engobo na parte interna e ungulações na face externa.

A partir dos 176 fragmentos de borda, foi possível reconstruir, com segurança, a forma de seis vasilhas. Uma vez que se conta, no Sítio Alvorada, com formas de contornos complexos, fica comprometida a classificação dos fragmentos de borda muito pequenos, para os quais se desconhece a continuidade do contorno. 
Neide Barrocá Faccio

Hiuri Marcel Di Baco

Juliana Aparecida Rocha Luz

André Felipe Alves
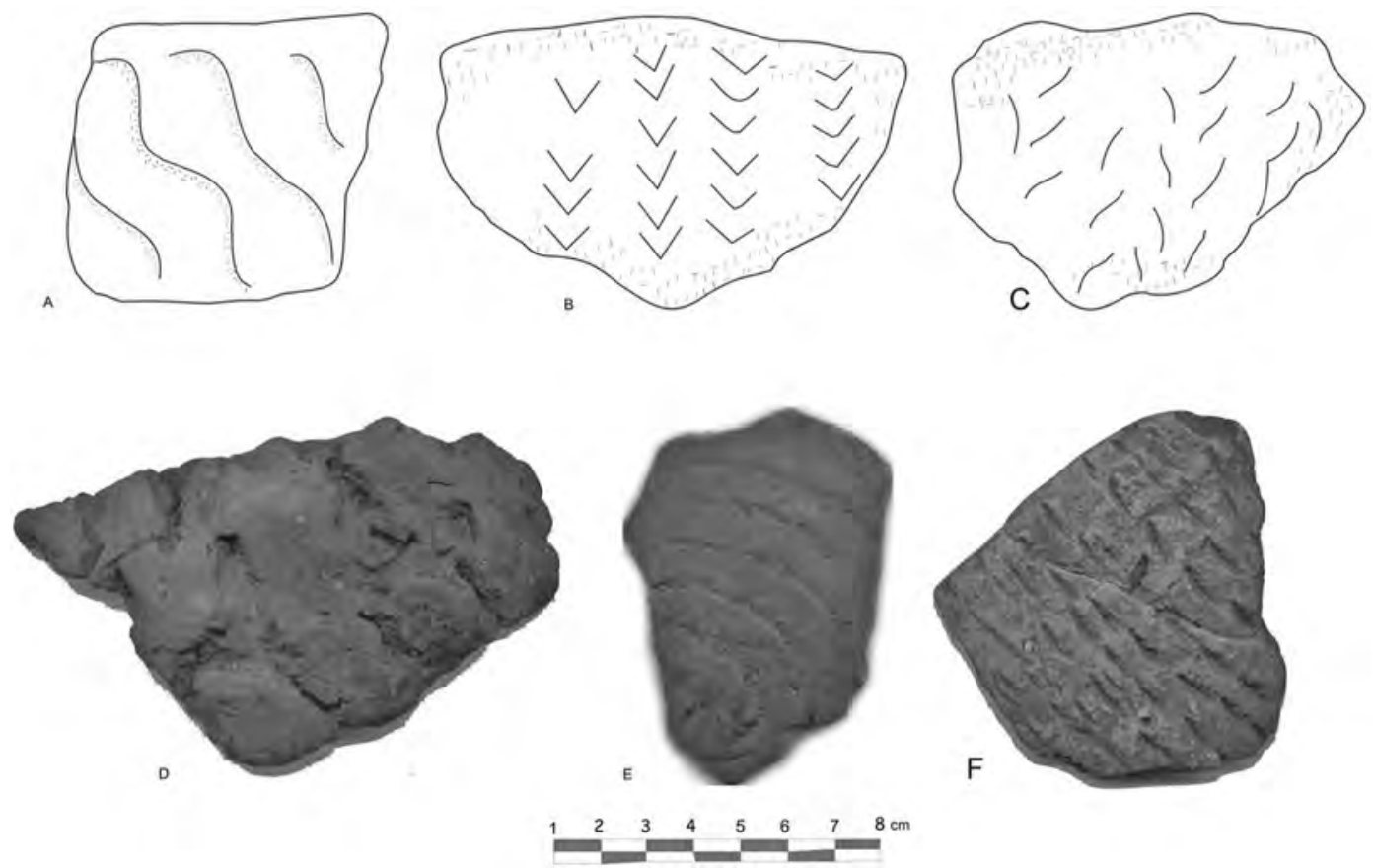

Prancha 1. Decorações Plásticas do Sítio Alvorada: A - Decoração plástica, apresentando corrugados sinuosos, aplicados por meio da pressão dos dedos polegar e indicador ou de espátula sobre os roletes ou sobre a superfície alisada da argila ainda mole. B - Decoração plástica, apresentando serrungulado paralelos aplicados por meio da pressão das pontas dos dedos com as unhas sobre a superfície da argila ainda mole, distando entre si 0,3 a $0,6 \mathrm{~cm}$. C - Decoração plástica, apresentando ungulado em sentido irregular, aplicado por meio da pressão das unhas ou de espátulas sobre a superfície da argila ainda mole. D - Decoração plástica, apresentando corrugado feito por pressão dos dedos polegar e indicador ou por espátula sobre a superfície externa. E - Decoração plástica, apresentando incisão linear, circulares paralelas, feitas por objeto pontiagudo ou por pressão sucessiva de unhas e pontas do dedo sobre a superfície externa alisada da parede de argila ainda mole, com espaçamento entre si de 0,5 a 0,8 $\mathrm{cm}$. F - Decoração plástica, apresentando ungulados paralelos em um mesmo sentido, com espaçamento entre si de 0,2 a 0,5 cm feitos por pressão de unhas ou espátula de madeira sobre a superfície da parede externa alisada. 


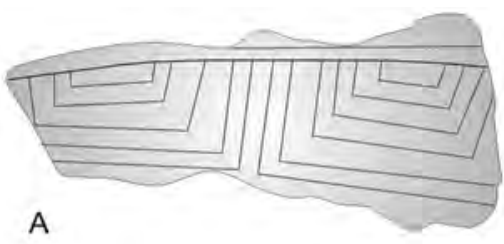

B
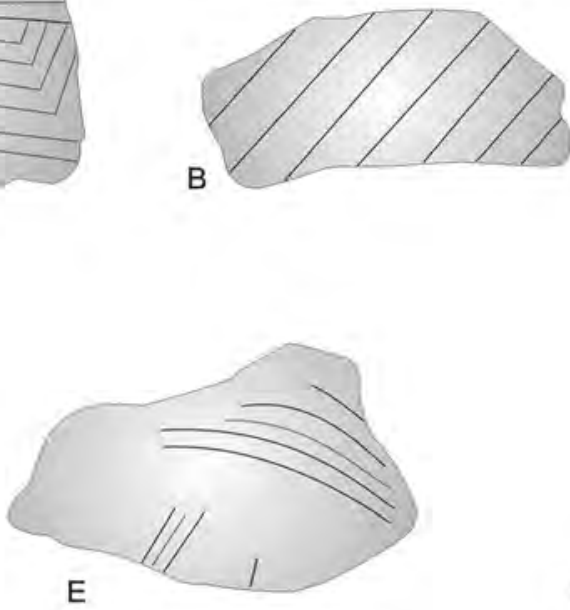

D

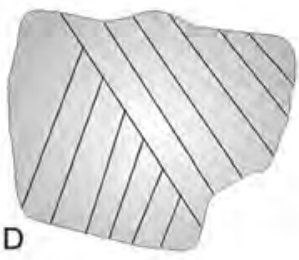

E

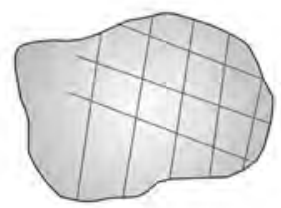

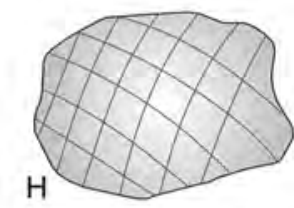
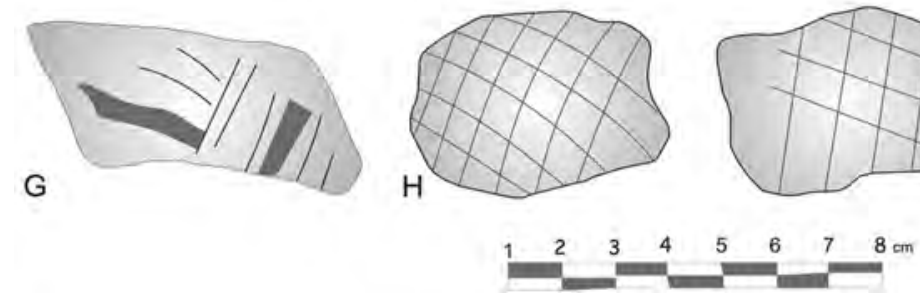

G

H
C

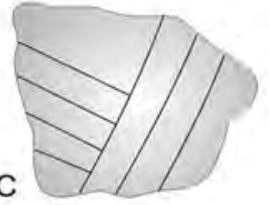

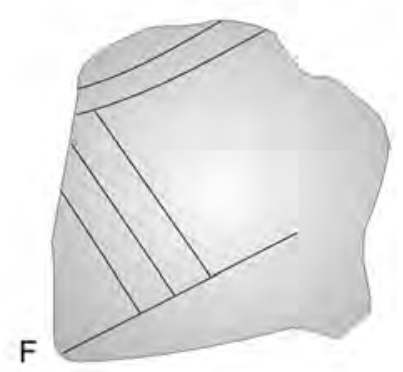

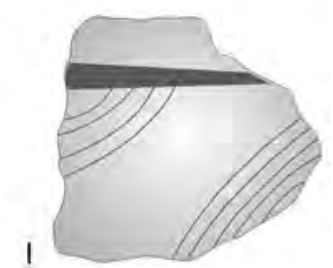

Prancha 2. Decorações Pintadas do Sítio Alvorada: A - Decoração pintada, apresentando linhas retas e paralelas, formando ângulos de 90 distando entre si 0,2 a 0,4 cm e uma linha marrom reta e contínua delimitando linhas vermelhas, sobre engobo branco ou creme. B - Decoração pintada, apresentando linhas vermelhas diagonais paralelas lineares, distando entre si 0,4 a 0,6 cm sobre engobo vermelho. C - Decoração pintada, apresentando linhas vermelhas paralelas lineares diagonais opostas formando ângulos de $90^{\circ}$, distando entre si $0,3 \mathrm{a} 0,5 \mathrm{~cm}$ sobre engobo branco ou creme. D - Decoração pintada, apresentando linhas vermelhas retas lineares diagonais opostas, distando entre si 0,3 a 0,4 cm sobre engobo branco. E - Figura com decoração pintada, apresentando linhas vermelhas e marrons curvas, retas paralelas distando entre si 0,2 a 0,4 cm sobre engobo branco ou creme. F - Decoração pintada, apresentando apenas duas linhas vermelhas curvas paralelas e linhas vermelhas diagonais formando ângulos de $90^{\circ}$ distando entre si 0,3 a 0,6 cm sobre engobo branco ou creme. G - Figura com decoração pintada, apresentando apenas uma faixa não linear e outra linear e linhas vermelhas paralelas e curvas, distando entre si 0,3 a 0,6 cm sobre engobo branco ou creme. H - Figuras com decoração pintada, apresentando linhas marrons curvas diagonais sobrepostas variando entre si 0,4 a 0,6 cm sobre engobo branco ou creme. I - Decoração pintada, apresentando apenas uma faixa vermelha a aproximadamente 1 centímetro da borda associada às linhas curvas distando entre si 0,3 a 0,2 cm sobre engobo branco ou creme. 
Neide Barrocá Faccio

Hiuri Marcel Di Baco

Juliana Aparecida Rocha Luz

André Felipe Alves
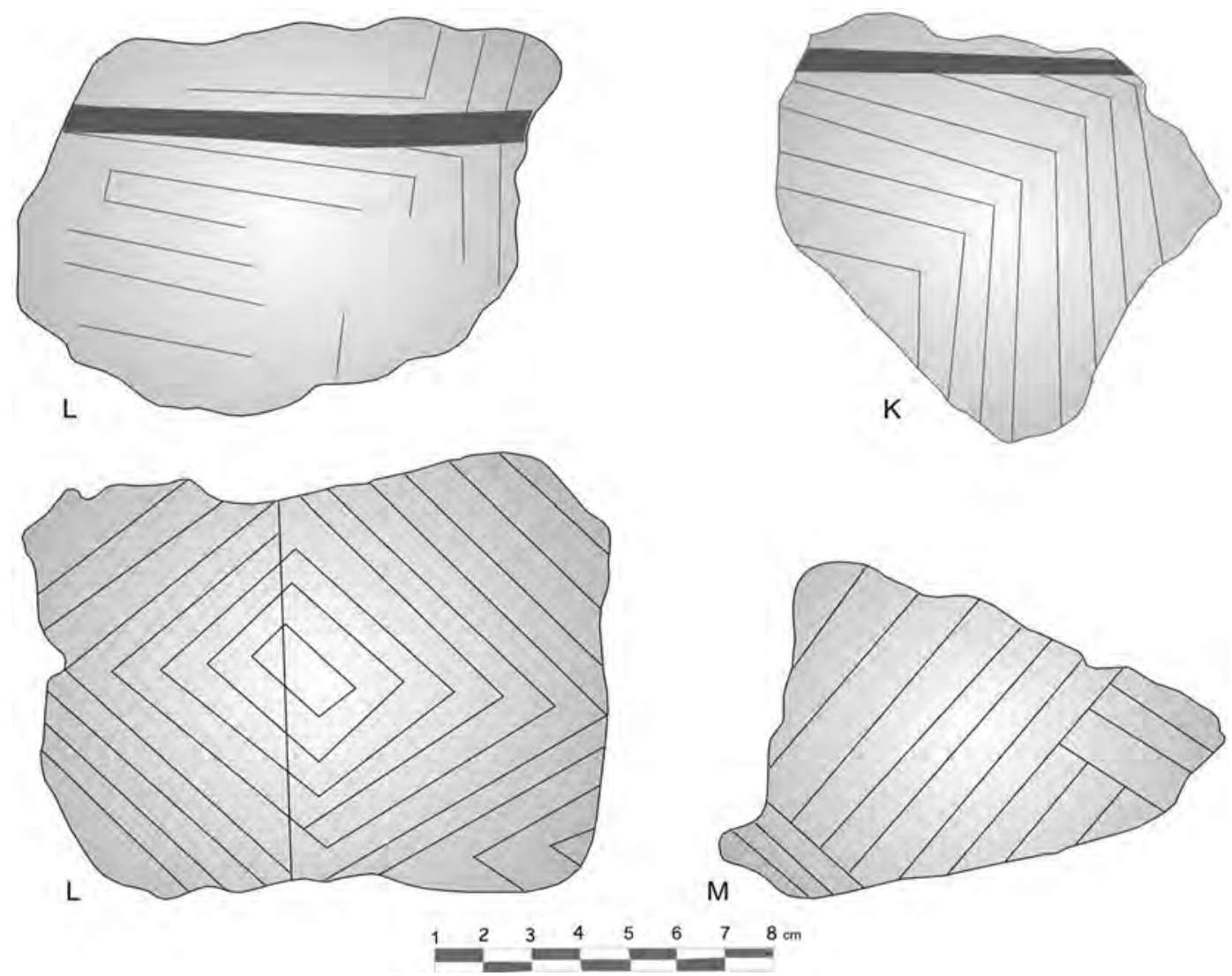

Prancha 3. Decorações Pintadas do Sítio Alvorada: J - Decoração pintada, apresentando apenas uma faixa vermelha de $0,5 \mathrm{~cm}$ e linhas vermelhas retas paralelas lineares formando ângulos de $90^{\circ}$, distando entre si 0,4 a $0,7 \mathrm{~cm}$ sobre engobo branco ou creme. K - Decoração pintada, apresentando apenas uma faixa vermelha e linhas paralelas lineares formando ângulos que variam entre si $90^{\circ}$ a $120^{\circ}$ sobre engobo branco ou creme. L - Decoração pintada, apresentando apenas uma linha vermelha reta sobre linhas vermelhas retangulares variando entre si 0,3 a $0,8 \mathrm{~cm}$ sobre engobo branco ou creme. M - Decoração pintada, apresentando linhas vermelhas paralelas diagonais opostas formando ângulos de $90^{\circ}$, distando entre si 0,3 a 0,9 cm sobre engobo branco ou vermelho. 
Estudo da cerâmica do sítio arqueológico Alvorada, da região do Rio Aguapeí, estado de São Paulo.

R. Museu Arq. Etn., São Paulo, n. 21, p. 275-292, 2011.
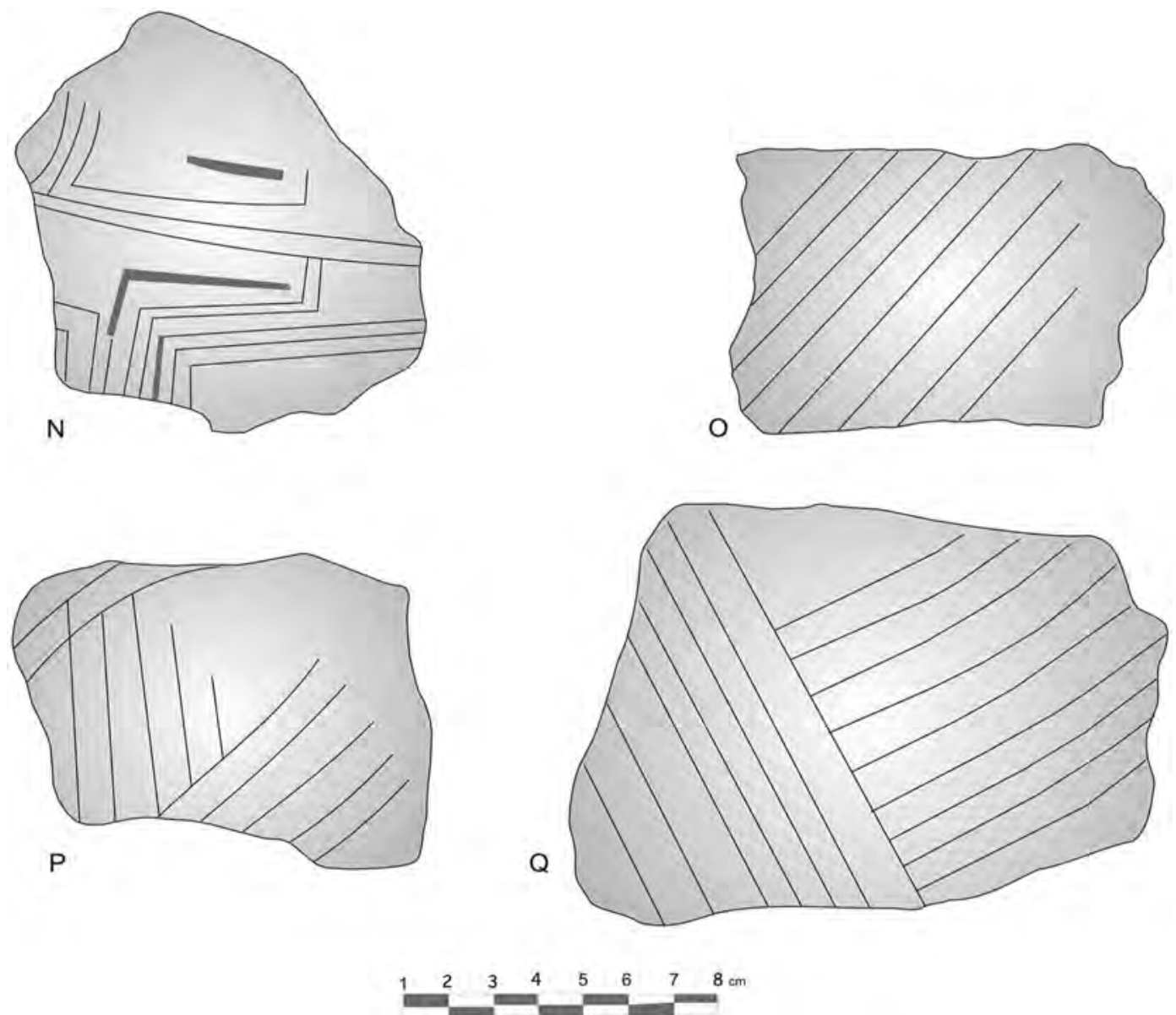

Prancha 4. Decorações Pintadas do Sítio Alvorada: N - Decoração pintada, apresentando linhas vermelhas lineares e curvas paralelas formando ângulos de $90^{\circ}$, distando entre si 0,2 a 0,4 cm e faixas marrons formando ângulo de $90^{\circ}$ entre linhas vermelhas sobre engobo branco. O - Decoração pintada, apresentando linhas vermelhas diagonais distando entre si 0,5 a 0,7 cm sobre engobo branco ou creme. P. Decoração pintada, apresentando linhas vermelhas retas e curvas opostas, formando ângulos de 30\%, distando entre si 0,5 a 0,7 cm sobre engobo branco ou creme. Q - Decoração pintada, apresentando linhas vermelhas diagonais paralelas retas e curvas, formando ângulos de $90^{\circ}$, distando entre si 0,4 a $0,8 \mathrm{~cm}$ sobre engobo branco ou creme. 
Neide Barrocá Faccio

Hiuri Marcel Di Baco

Juliana Aparecida Rocha Luz

André Felipe Alves
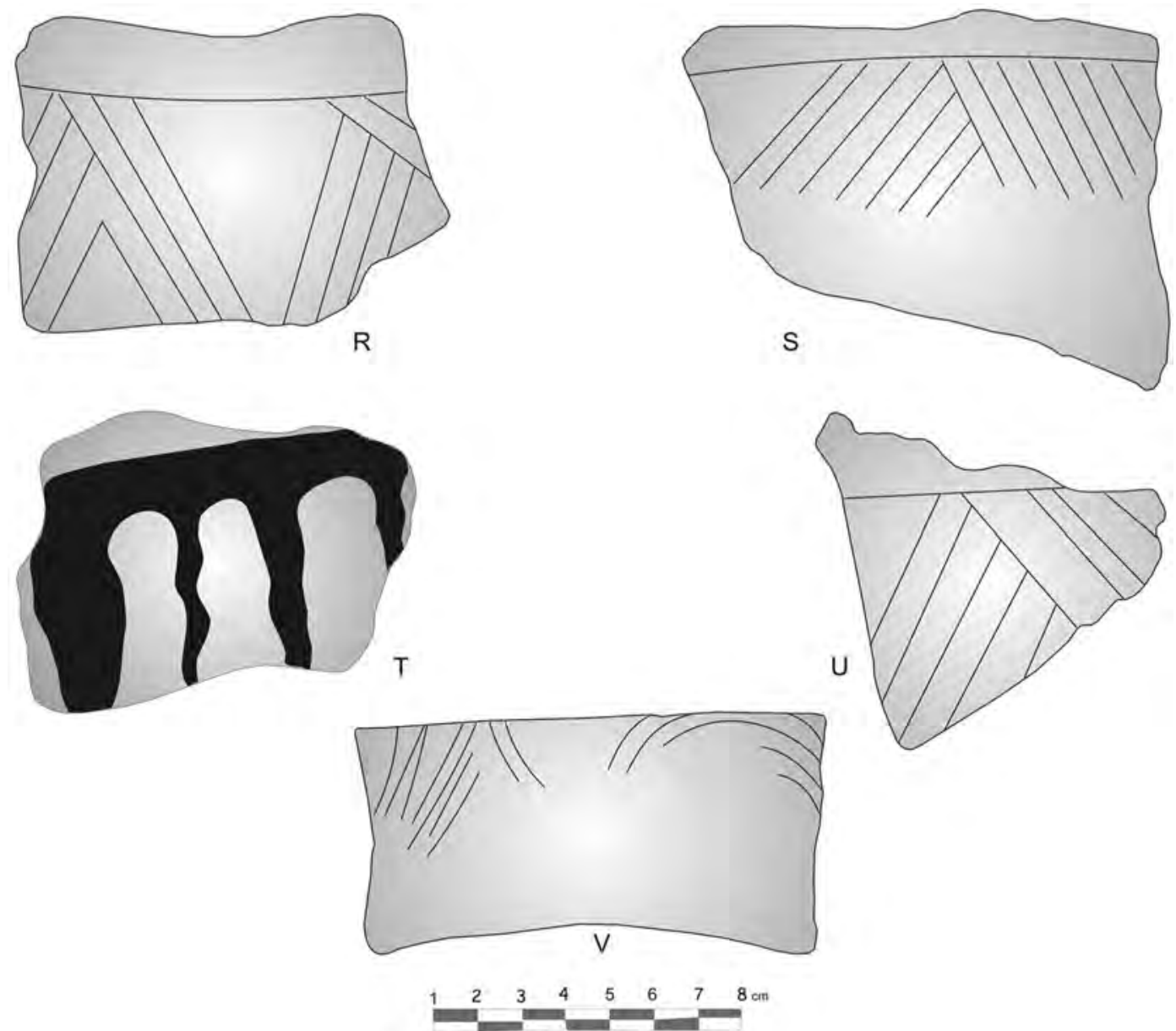

Prancha 5. Decorações Pintadas do Sítio Alvorada: R - Decoração pintada, apresentando linhas vermelhas diagonais opostas formando ângulos de 30, distando entre si 0,3 a $0,5 \mathrm{~cm}$, delimitadas na parte superior por uma linha horizontal reta, sobre engobo branco ou creme. S - Decoração pintada, apresentando linhas vermelhas diagonais opostas formando ângulos de $30^{\circ}$, distando entre si 0,3 a $0,5 \mathrm{~cm}$, delimitadas na parte superior por uma faixa horizontal reta, sobre engobo branco ou creme. T - Decoração pintada, apresentando faixas pretas sinuosas aplicadas diretamente sobre a superfície da vasilha. U - Decoração pintada, apresentando linhas vermelhas lineares diagonais opostas paralelas formando ângulos de $30^{\circ}$, distando entre si 0,3 a $0,5 \mathrm{~cm}$, delimitadas na parte superior por uma linha horizontal reta sobre engobo branco ou creme. V - Decoração pintada, apresentando linhas curvas e retas paralelas, distando entre si 0,2 a 0,5 cm sobre engobo branco ou creme. 


\section{Reconstrução da forma das vasilhas cerâmicas conjugadas por modelagem, remontagem e restauro a partir dos fragmentos}

A técnica de reconstrução da forma é estruturada a partir do objeto que pretendemos recuperar. No caso de peças arqueológicas, é necessário ter um cuidado maior, pois não podemos descaracterizar sua forma original no desenvolvimento do trabalho de remontagem e restauro.

Para tanto, a organização do trabalho é fundamental, haja vista estarmos diante de um artefato antigo que se encontra aos pedaços. Desse modo, devemos estruturar nosso pensamento no cuidado da descrição dos fragmentos que temos em mãos. A partir desse arranjo, a boa disposição e a paciência são fundamentais para conseguirmos dar vida às combinações de fragmentos que, em ordem, possibilitarão recompor a forma original da vasilha.

No procedimento de restauro devemos, primeiramente, limpar as peças com um pincel e, se for necessário, lavar os cortes dos fragmentos banhando-os em água e limpando-os com uma escova de cerdas macias. Contudo, devemos evitar a lavagem das peças sempre que possível. Em seguida, o s fragmentos são postos para secar em temperatura ambiente, longe da luz do sol. Estando as peças limpas, iniciamos o processo de organização dos fragmentos em conjuntos que compõem uma mesma parte da vasilha, ou no caso de borda, o preparo para reconstrução gráfica da forma. Assim, temos conjuntos de fragmentos para cada uma das partes que compõem a peça, ou seja, conjuntos de fragmentos que compõem a base, parede e borda ou ainda bordas aptas a reconstrução gráfica da forma.

O procedimento de reconstrução e projeção das vasilhas considerou as características tanto do ângulo de inclinação do contorno, como a porcentagem do diâmetro da circunferência dos fragmentos de borda. Dessa forma, fizemos a reconstrução gráfica da forma de 11 projeções gráficas, representando as propriedades de parte da forma desses recipientes (Prancha 6: desenhos A, B, C, D, E, F, G, H, I J, K e L) e de seis vasilhas (Prancha 6: desenhos $\mathrm{L}, \mathrm{M}, \mathrm{N}, \mathrm{O}$, P e Q).

A vasilha conjugada apresentada na letra Q, da prancha 6, constitui uma forma típica da Tradição Aratu, embora o Sítio Alvorada tenha sido classificado na Tradição Tupiguarani.

A Foto 1 apresenta o fragmento de borda, a partir do qual foi restaurada a forma da vasilha conjugada. A foto 2 apresenta o fragmento de borda e a forma da vasilha reconstruída graficamente.

Para a reconstrução das vasilhas conjugadas, misturamos a argila pura com a cola branca, solúvel em água, não tóxica, até obter uma pasta homogênea. A modelagem da forma foi feita após a projeção gráfica da forma da vasilha no papel vegetal (Fotos 3 e 4).

No processo, modela-se a argila, para completar possíveis partes que estão faltando, ou seja, deve-se modelar com a argila as partes ausentes da vasilha. Nas fotos 5 e 6 podemos observar as formas das vasilhas conjugadas depois de modeladas e reconstruídas.

Terminada essa fase deixamos a peça secar. Após a secagem, limpamos a parte original das vasilhas com um pedaço de flanela úmida. A limpeza tem por objetivo retirar o excesso de argila e cola presentes na peça. Depois da vasilha reconstituída e limpa, utilizamos tintas guache, que é um pigmento solúvel em água, para atenuarmos as marcas das fraturas e diferenciar o que foi reconstruído do fragmento original da peça.

Nesse processo, as cores mais utilizadas são o marrom, o amarelo, o preto, o vermelho e o branco. Para a aplicação dos pigmentos, utilizamos um pincel pequeno de formato chato e pelos duros ou as próprias pontas dos dedos.

A metodologia apresentada aponta para o uso em futuras restaurações e reconstruções por modelagem, contribuindo, assim, para que vasilhas fragmentadas e artefatos em processo de deterioração possam ser preservados e fazer parte das coleções expostas no museu. 
Neide Barrocá Faccio

Hiuri Marcel Di Baco

Juliana Aparecida Rocha Luz

André Felipe Alves

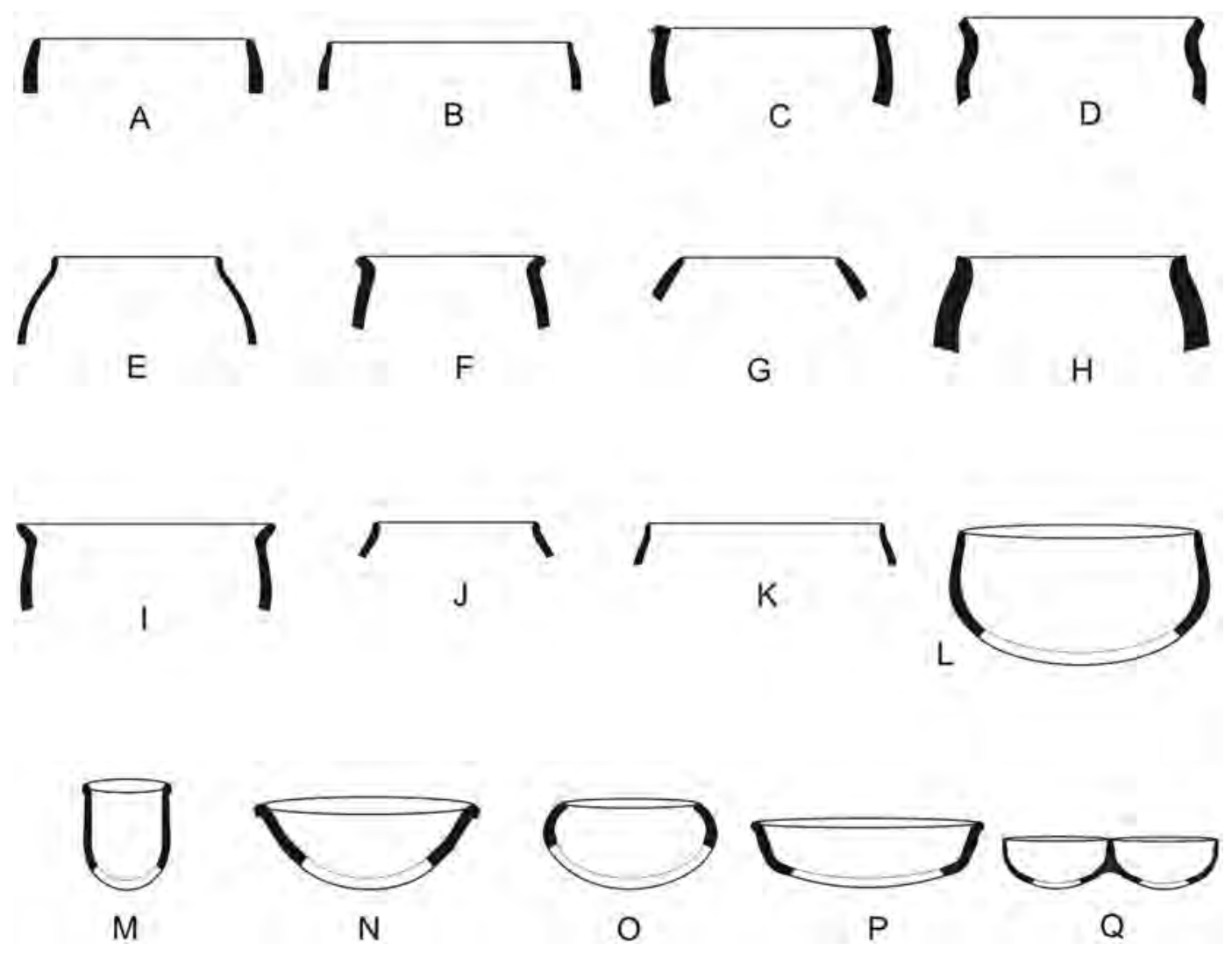

Prancha 6. Reconstrução Gráfica do Diâmetro e Forma das Vasilhas do Sítio Alvorada:

A - Abertura constrita, lábios arredondados. Diâmetro $26 \mathrm{~cm}$. B - Abertura constrita, lábios arredondados com reforço na parte externa. Diâmetro $34 \mathrm{~cm}$. C - Abertura constrita, lábios arredondados com reforço na parte externa. Diâmetro $26 \mathrm{~cm}$. D - Abertura constrita, lábios arredondados. Diâmetro $28 \mathrm{~cm}$. E - Abertura constrita, lábios arredondados. Diâmetro $22 \mathrm{~cm}$. F - Abertura constrita, lábios arredondados. Diâmetro $24 \mathrm{~cm}$. G - Abertura constrita, lábios arredondados. Diâmetro $20 \mathrm{~cm}$. H - Abertura constrita, lábios arredondados. Diâmetro $26 \mathrm{~cm}$. I - Abertura ampliada, lábios arredondados. Diâmetro $32 \mathrm{~cm}$. J - Abertura constrita, lábios arredondados com incisão. Diâmetro $20 \mathrm{~cm}$. K- Abertura constrita, lábios arredondados com reforço externo. Diâmetro $30 \mathrm{~cm}$. L Tigela funda de contorno complexo e forma contraída. Lábios arredondados com reforço externo. Volume: 8,85 litros. M - Miniatura de vasilha de contorno simples. Forma alongada. Lábios arredondados. Volume: 0,09 litros. $\mathrm{N}$ - Tigela rasa, de boca ampliada, contorno simples, forma meia-esfera. Lábios arredondados. Volume: 6,18 litros. O - Tigela funda de contorno complexo e forma infletida. Lábios planos. Volume: 0,67 litros. P - Tigela rasa de contorno complexo e forma contraída. Lábios arredondados. Volume: 4,26 litros. Q - Tigelas pequenas conjugadas de contorno simples. Forma meia-esfera. Lábios arredondados. 

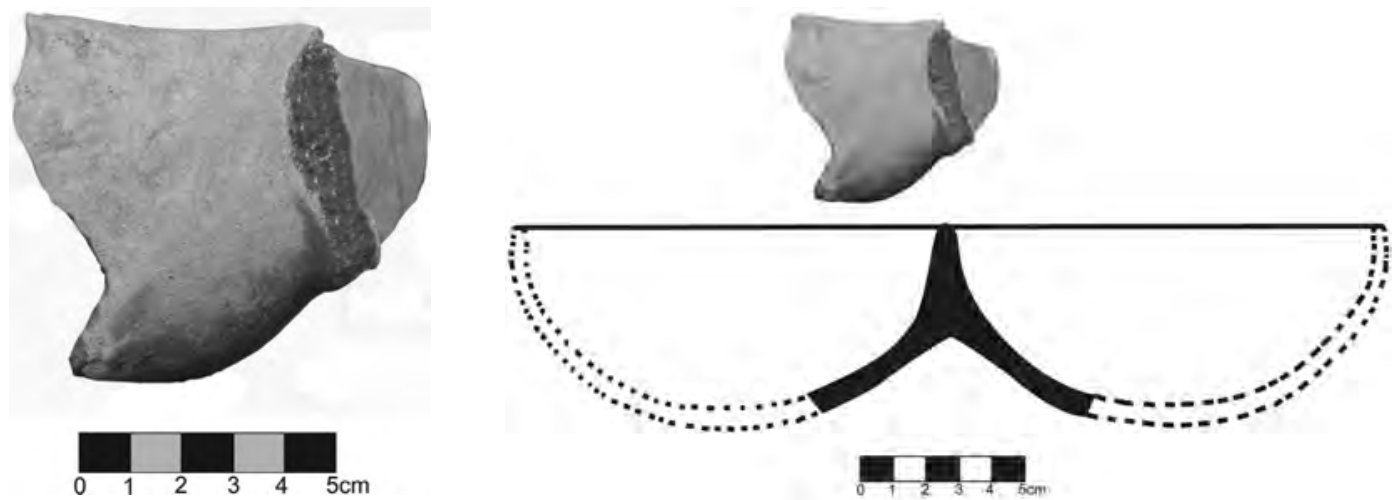

Fotos 1 e 2. Organização do fragmento e reconstrução gráfica da forma da vasilha a partir do fragmento de borda. Sítio Alvorada, Junqueirópolis, SP.
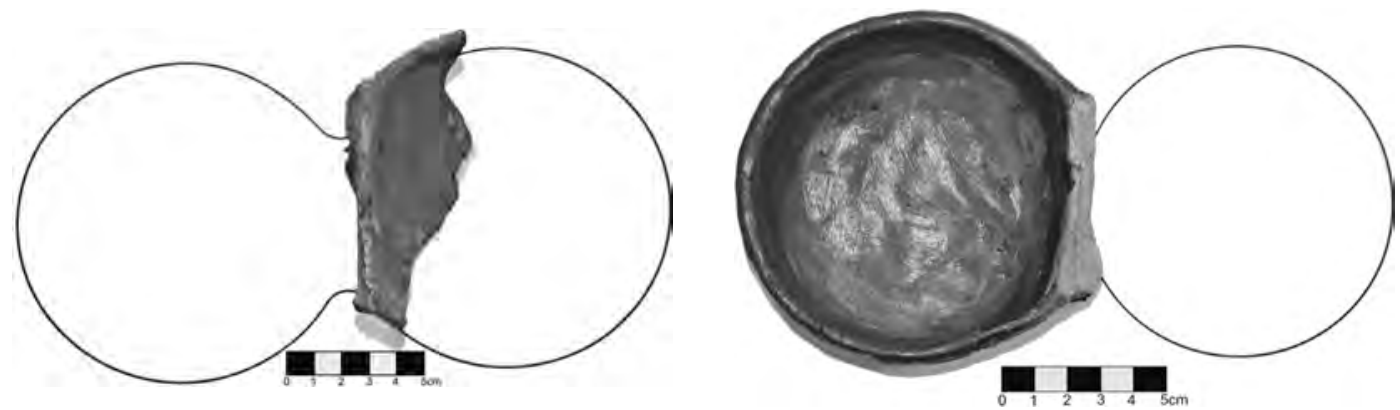

Fotos 3 e 4. Reconstrução da forma da peça por meio da técnica de modelagem. Sítio Alvorada, Junqueirópolis, SP.

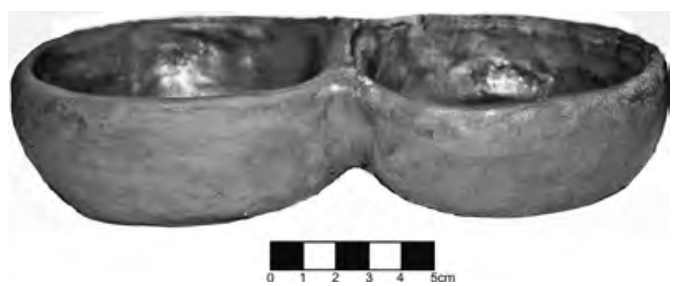

Fotos 5 e 6. Forma da vasilha reconstruída. Sítio Alvorada, Junqueirópolis, SP.

\section{Considerações finais}

A área do Sítio Arqueológico Alvorada vem sendo arada e subsolada há, pelo menos, 20 anos. Dessa forma, os impactos nos vestígios arqueológicos dos sítios foram intensos, constantes e irreversíveis. Com isso, o resgate do material arqueológico em situação de risco foi considerado

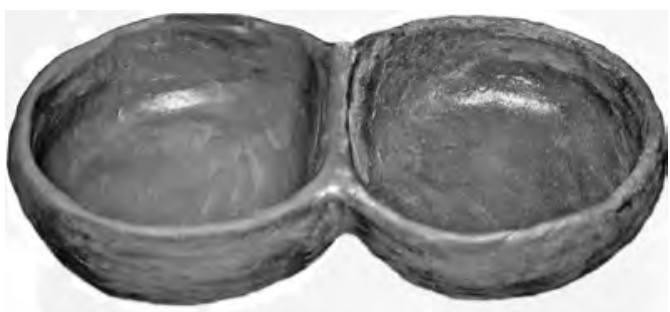

Q

como uma das medidas de um plano de resgate que abordou a área do sítio como um todo. Com essas intervenções acreditamos que o disposto nas Portarias 7 e 230 do IPHAN foi cumprido.

É importante ressaltar que a história de Junqueirópolis, SP, era conhecida por meio de documentos textuais esparsos e por tradição oral; no entanto, essa é a história de poucos. 
Esta pesquisa contribuiu para o conhecimento de aspectos da História Local e da Arqueologia, bem como da preservação e promoção do patrimônio arqueológico local.

O trabalho apresenta as reflexões, colocadas para a área do Sítio Arqueológico Alvorada. Sabendo das inúmeras possibilidades de análise e interpretações que os materiais evidenciados suscitam, este projeto, objetivando a geração de conhecimentos, primou por fornecer dados primários para o estudo e discussão acerca da ocupação pretérita da região compreendida pelas bacias dos rios Aguapeí/Feio e Peixe.

Existem evidências de possíveis contatos e/ ou influências das Tradições Itararé (brunidura) e Aratu (vasilha de forma conjugada) na cerâmica Tupiguarani do Sítio Alvorada, possibilitando diferentes formas de interpretação. A brunidura e a vasilha de forma conjugada em um sítio da Tradição Tupiguarani podem expressar as facetas de uma área onde os territórios indígenas, do período pré-colonial, ainda não são conhecidos. Isso aponta para um problema de pesquisa que ainda precisa ser avaliado usando-se estudos comparados.

As análises estatísticas dos materiais evidenciados no sítio ajudaram a entender a variabilidade formal, estilística e quantitativa, cruzar variáveis e classificar os tipos de artefatos.
Na análise da cerâmica do Sítio Alvorada, percebemos o uso da técnica de manufatura acordelada, a queima incompleta, o uso de argila com conteúdo de carbono e o antiplástico mineral associado ao caco moído de forma predominante. $\mathrm{Na}$ análise da forma e da decoração, predominam as com características da Tradição Tupiguarani.

Quanto aos tipos cerâmicos do Sítio Alvorada verificou-se a presença do corrugado, serrungulado, ungulado, canelado, digitado, escovado, entalhado, inciso, pintado e engobo branco/bege e vermelho. A variabilidade da decoração das vasilhas do Sítio Arqueológico Alvorada, principalmente, no que diz respeito à pintura, é ponto de destaque, mesmo tendo em vista ser essa uma das características da Tradição Tupiguarani. A variabilidade dos motivos da pintura da cerâmica do Sítio Alvorada apresenta algumas similaridades com a cerâmica Guarani da área do Vale do Rio Paranapanema, lado paulista, mas no atual estágio das pesquisas não podemos fazer associações. Cita-se, como exemplo, a raridade da pintura em faixas pretas diretamente sobre a superfície da cerâmica, ocorrência vista numa vasilha do Sítio Alvorada. Tal decoração não é usual na Tradição Tupiguarani, mas foi evidenciada com pouca frequência na cerâmica de sítios localizados na área do Baixo Paranapanema, como é o caso do Sítio Alvim, Município de Pirapozinho, SP.

FACCIO, N.B.; BACO, H.M.D; LUZ, J.A.R.; ALVES, A.F. Study of the ceramic of Alvorada archaeological site, region of Aguapeí River, State of São Paulo. R. Museu Arq. Etn., São Paulo, n. 21, p. 275-292, 2011.

Abstract: The study of the ceramic of Alvorada archaeological site, situated in Junqueirópolis City, State of São Paulo, aimed at getting information about indigenous population that occupied the area. Due to the characteristics of the site and the gaps existent in the regional and historical memory, the incorporation of this information is extremely valuable to the regional and national memory. The ceramic found at Alvorada Archaeological Site has characteristics of Tupiguarani ceramic, although we have found traces of another archaeological tradition, which implies contact between peoples that speak either tupiguarani and Jê language or their derivations.

Keywords: Ceramic - Tupiguarani Tradition - Alvorada archaeological site National Memory. 


\section{Referências bibliográficas}

ARNOLD, D,

1984 Serial interaction and ceramic design: community wide correlates in Quinua, Peru. In: Rice, P.M. (Ed.) Pots and Pottery. Los Angeles, Uni. of Califórnia: 62-133.

CHMYZ, I. (Ed.)

1976 Terminologia arqueológica brasileira para cerâmica. Cadernos de Arqueologia, Paranaguá, 1, (1): 119-148.

FACCIO, N.B.

1991 O Estudo do Sítio Alvim e Sua Interação Com a Geografia. In: Associação dos Geógrafos Brasileiros. Anais do III Encontro de Geógrafos da América Latina. Toluca, México: 88-96.

1998 Arqueologia do Cenário das Ocupações Horticultoras da Capivara, Baixo Paranapanema. Tese de Doutorado em ArqueoloHODDER, I. gia. São Paulo, Universidade de São Paulo.

1978 Simple Correlation Between Material Culture and Society: a Review. In: Hodder, I. (Ed.) The Espatial Organization of Culture. Pittsburg, Duckworth: 3-24.

KINGERY, W.D.

1984 Interactions of Ceramic Technology With Rociety. In: Rice, P.M. (Ed.) Pots and Pottery. Los Angeles, Univ. of Califórnia: 78-171.

LIMA, T.A.

1987 Cerâmica Indígena Brasileira. In: Ribeiro, D. (Ed.) Suma Etnológica Brasileira, n. 2, Tecnologia Indígena. Finep, 2a ed. Petrópolis, Vozes: 173-229.

MARANCA, S.

1985 Dados preliminares para uma classificação do material cerâmico pré-histórico. Revista do Museu Paulista (Nova Série), São Paulo, 30: 235- 250 .

MORAIS, J.L.

1983 A Utilização dos Afloramentos Litológicos pelo Homem Pré-histórico Brasileiro: análise do tratamento da matéria-prima. Coleção Museu Paulista, 7. 212 p.
1999 Perspectivas geoambientais da Arqueologia do Paranapanema paulista. Tese de Livre-Docência. São Paulo, USP.

2006 Reflexões Acerca da Arqueologia Preventiva. In: Mori, V.H.; Souza, M.C.; Bastos, R.L.; Gallo, H. Revista do IPHAN Patrimônio: atualizando o debate, São Paulo: 191-220.

PROUS, A.

1992 Arqueologia Brasileira. Brasília: Ed. Universidade de Brasília.

RICE, P.

1984 Pots and Potters: current approaches in ceramic archaeology. Los Angeles: Institute of Archaeology, University of California.

SCATAMACCHIA, M.C.M.

1990 A Tradição policrômica no leste da América do Sul evidenciada pela ocupação Guarani e Tupinambá: Fonte arqueológicas e etno-históricas, 310 p. Tese de Doutorado. São Paulo, FFCLH, Universidade de São Paulo.

SCHIFFER, M.B.; SKIBO, J.

1987 Theory and Experiment in the Study of Technological Change. Current Anthropology, 28 (5): 595-622.

SCHORTMAN, E.M.

1989 Interregional Interction in Prehistory: the need for a new perspective. American Antiquity, 54 (1): 25-65.

SILVA, F.A.

2000 As Tecnologias e seus significados. Um estudo da cerâmica dos Assuriní do Xingu e da cestaria dos Kayapó-Xikrin sob uma perspectiva etnoarqueológica. Tese de Doutorado. São Paulo, FFLCH, Universidade de São Paulo.

STEPONAITIS, V.P.

1983 Ceramics Chronology and Community Pattern. New York: Academic Press.

WILLEY, G.R.

1987 Cerâmica. In: Ribeiro, D. (Ed.) Suma etnológica brasileira, n. 2, Tecnologia Indígena. Finep, 2a ed. Petrópolis, Vozes: 231-282. 